Revisiting Port Governance and Port Reform: A Multi-country Examination Special volume of Research In Transportation Business \& Management

\title{
From National Reforms to Local Compromises: The Evolution of France's Model for Port Management, 2004-2015
}

\section{Revised version}

12 Dec. 16

Jean Debrie, Professor, University Paris 1 Pantheon-Sorbonne, UMR Géographie-cités Romuald Lacoste, Researcher, CEREMA (French Ministry of Ecology, Energy and Sea) Marion Magnan, PhD Student, IFSTTAR/SPLOTT (University of Paris East) 
Revisiting Port Governance and Port Reform: A Multi-country Examination

Special volume of Research In Transportation Business \& Management

\section{From National Reforms to Local Compromises: The Evolution of France's Model for Port Management, 2004-2015}

\section{Introduction. The Evolution of Port Governance in France}

The evolution in the governance of ports throughout the world since the 1980s has led to a profound change in the interaction between public and private actors. To be sure, these changes have not been homogenous, and have not led to the emergence of a single model for organising ports. Nevertheless, the shift to a market-based model has guided change in public policy, within a context of liberalising service activities, and now exists on all harbour fronts. Moreover, the investment needs accompanying the processes of massification and concentration have favoured the emergence of new forms of public-private partnerships everywhere, and a general move to port concessions. Numerous studies have examined these trends in detail. Many researchers have also discussed and enriched the model put forward by the World Bank in its "Port Reform Toolkit", clarifying: the roles of actors (Brooks \& Pallis, 2008 \& 2010, Cullinane \& Song, 2002); the consequences for the evolution of the roles of public actors and especially port authorities (Comtois \& Slack, 2003; Verhoeven P, 2010); as well as the impact of this evolution on port performance (Brooks \& Pallis, 2008). The analysis of different port reforms has allowed the rising role of private operators to be clarified. It has also explained the diversity of public organisations (De Langen \& Van der Lugt, 2007; Brooks M. R., Cullinane K., 2006; Palis, 2007, Wang \& al, 2003, etc.). Such research has mainly concentrated on large ports, though some work has also taken place concerning the devolution and decentralisation processes which have modified the governance of regional and national ports too (Debrie \& Lavaud-Letilleul, 2010).

The French case provides a good example of this shift in port governance. Reforms have occurred later than in other European countries, but they have successively led to the devolution (in 2004) of 17 ports of "national interest" and a change in status of France's seven main ports (in 2008). The aim of this paper is to analyse these two recent reforms, as well as their consequences for French ports, in order to contribute to "the multi-examination of port governance and port reform" (Special volume of Research In Transportation Business \& Management). The main objective is to clarify the context of these reforms, the processes modifying the port model and their consequences on the evolution of port management.

Section 1 sets out the changes in the industrial context facing ports, reviewing the impact of the breakdown of the Fordist economy during the 1970s. The next section explains how a new port model emerged from these two reforms, leading to the devolution of ports of national interest and the change in status of autonomous ports, which together led to France's new port model. Section 3 then looks at how these two reforms affected negotiations between actors, leading to a new organisation and strategy for ports. Lastly, we examine the results of 
reforms, presenting the positive aspects of these changes, but also pointing to criticisms that can be identified in the wake of reforms (Section 4). This section therefore reviews the outcomes of the reform process by contrasting the modification of port governance with industrial policies related to ports.

\section{Contextual Issues: The Political and Economic Crisis of the Port Model at the End of the Post-War Boom}

The recent changes (2004-2016) in the governance of French ports needs to be put into a longer term perspective, in other words the crisis of the industrial-port system that was created in France during the long post-war boom. To review this long term development path, we start by recalling the main characteristics of port policy that were implemented between the 1950s and the mid-1970s, prior to examining the economic and political factors which subsequently brought them into question.

The long post-war boom (known as the "Glorious Thirty" - Trente Glorieuses - in French due to the profound economic and social transformation of society [Fourastié, 1979]) was marked by strong interventionism by the State (France's central government). In the economy, this was carried out by a system of medium-term plans implemented and piloted by the French Planning Agency (Commissariat general au plan) created in 1946. At the same time, regional development planning emerged in 1963, when the DATAR was created (the Delegation for territorial planning and regional action, or Délégation à l'aménagement du territoire et à l'action régionale). France's ports found themselves at the crossroads of these centralised planning policies. The post-war period was thus characterised by an active modernisation policy of port infrastructures and services, based on the maritime industrial development model (MIDA) which emerged in the Rhineland. This involved integrating port and industrial activities in the same coastal areas. The fundamental principle was to create "industry with its feet in the water" or "ships in factories": industrial sites (in iron \& steel or petrochemicals) were built on the quayside, while port facilities were adapted to the continued growth in the size of ships. This model involved much land use, so that port functions moved outside towns, and downstream towards estuaries [Bird, 1963].

France's port policy was thus based on vast programmes to create industrial-port zones launched and supervised by the State. Three sites - the "majors" - were concerned, namely Dunkirk, Fos-sur-Mer and Le Havre [Vigarié, 1984], followed by secondary ports like SaintNazaire or Bordeaux with the development of Montoir and Le Verdon. The implementation of these programmes was reflected financially by an increase in State funds provided for the investment and operation of the port sector, as shown in Graph 1.

Table 1: The Evolution of the Annual Average State Budget for Ports, 1960-1975

While the whole of France's port system benefited from this policy and its accompanying funding at the time, State intervention was focussed especially on six ports, which became 
autonomous ports in $1965 .{ }^{1}$ This reform allowed State supervision of these ports' management to be reinforced. The authorities of the autonomous ports became a kind of public contractor of the State's policy on ports. However, this policy was destabilised in the mid-1970s, in the wake of radical economic and political changes.

Firstly, from an economic point of view, the oil shocks of the 1970s and the ensuing crisis impacted strongly on the industrial-port zones, which experienced a first wave of deindustrialisation and falls in traffic [Damette \& Schiebling, 1995]. The shipping industry also experienced major restructuring in parallel, which affected the port sector. Containerisation led to the rationalisation of port services by shipowners and the concentration of maritime traffic on fewer ports, according to the hub-and-spoke model [Frémont, 2005]. In selecting which ports to service, shipowners focussed on the quality provided by ports in terms of unloading speed and reliability on the one hand [Cour des comptes, 1999], and the adequacy of port infrastructure in meeting the continued growth in ship size.

In the face of rising European competition, French ports were penalised by their poor performance in the cargo handling sector [Cour des comptes 1999 et 2006], and the absence of significant investment in port facilities. As a result, French ports' competitiveness fell with respect to their European competitors, leading to a fall in their market shares: down by $21 \%$ for all traffic between 1989 and 2004, by $22 \%$ for solid bulk traffic and by 54\% for all types of container traffic [Cour des comptes, 2006]. ${ }^{2}$ Ports of "national interest" were on the whole less affected by these trends than were autonomous ports, because the former are integrated into economic territories or areas having a regional dimension. These ports are therefore more specialised in certain types of maritime traffic and industries. Overall, ports of national interest saw their share of total French port traffic rise between 1970 and 2000, increasing from $13.7 \%$ to $20.4 \%$, although the evolution of these ports varied substantially [Isemar, 2002]. Calais is by far the largest, and experienced exponential growth in its traffic in this period, linked to cross-channel traffic. ${ }^{3}$ The other ports are much more dependent on some shippers and industries, and are therefore easily destabilised by changes in the economic outlook.

The stagnation of France's port system during the last decades of the $20^{\text {th }}$ century was accentuated by the disengagement of the State from this sector, both in terms of policy and finance. A break came with the changing presidency in 1974, which saw all reference to ports disappear from economic planning formulated by the French Planning Agency. In fact, the Seventh Plan launched in 1976 provided for no significant investment in ports, compared to previous plans, and was entirely geared to fiscal consolidation. The progressive rundown of planning which took place subsequently was not accompanied by the emergence of any other type of policy for supervising the port sector. In this context, State funding of ports fell off

\footnotetext{
1 The six ports were Dunkirk, Le Havre, Rouen, Nantes-Saint-Nazaire, Bordeaux and Marseille-Fos.

$2 \quad$ The Cour des comptes (France's Court of Accounts) draws on non-public data provided by the Conseil général des ponts et chaussées - Direction des transports maritimes, routiers et fluviaux.

3 Traffic through the port of Calais rose from less than five million tonnes in 1975 to more than 40 million tonnes in the early 2000 s.
} 
noticeably: as of the early 1980s spending fell to levels prevailing in 1960 [Cour des Comptes, 2006].

France's Court of Accounts has on numerous occasions criticised the dispersion of State resources and the lack of clear policy guidelines [Cour des comptes, 1990 and 1999]. As of 1980, the State undertook to modify its degree of involvement in ports. The aim was to concentrate State/central government resources in a small number of sites under its direct supervision, (including six autonomous ports and about twenty ports of national interest) with the first wave of port devolution that took place in 1983: the responsibility of more than 500 small trading and fishing ports, as well as marinas was devolved to local government [Debrie \& Lavaud-Letilleul, 2010].

At the same time, there has been a progressive standardisation of port governance models, which the French system only conformed to lately. As of the 1990s, the "landlord port" model spread to a majority of the world's large ports [Brooks \& Cullinane, 2006]. It is characterised by public ownership and management of infrastructures, which contrasts with the private ownership and use of cargo handling facilities. In France, ports still operate according to the "tool model": the port authority manages the infrastructure and the operations of the port, both as an employer of dockers and as an owner of cargo handling equipment. A first attempt at reforming the handling system occurred in 1992, with Law No 92-496 which modified the regime governing the work of dockers. It aimed to end the intermittent employment regime that emerged in 1947, and also to authorise and encourage the recruitment of dockers by private cargo handling companies. This law did allow productivity to rise in docking terminals, but was seen as being incomplete by many observers. Indeed, crane operators were not affected by the law, and remained employees of the port authorities, which furthermore retained ownership of cargo handling equipment [Cour des comptes, 1999; Sénat, 2008].

The late 1990s and the first half of the 2000s were also characterised by a growing challenge to the economic and political foundations of the port system, as it had been established during the post-war boom. These observations led in 2006 to a report by France's Court of Auditors which stressed the "pressing need to act", in other words the necessity of profound reform of France's port policy [Cour des comptes, 2006].

\section{The Devolution of Ports of National Interest and Modifications in the Status of Autonomous Ports: the New Model of French Ports}

This challenge to France's port policy, which was formulated in different reports and especially by that of the Court of Accounts, drove reform of French ports. Two reforms thus changed the organisation of the French port model: one was general and concerned devolution in France (2004), while the other was specific and related to autonomous ports (2008). 
The Law of 13 August 2004 on local freedoms and responsibilities is considered to be France's second step to devolution. Article 30 of the Law transfers the ownership, development, maintenance and management of 17 ports of "national interest" to local authorities and their groupings. France's main ports (the seven autonomous ports) were not affected by this reform. But the Law nevertheless transferred 17 ports to local authorities, which at the time of transfer represented $20 \%$ of goods traffic by tonnage and nearly $80 \%$ of passenger traffic nationally. The Law thus led to the expanded competence over ports for local authorities at the regional and departmental level, as well as for mixed trade associations. Two legislative procedures in France actually initiated devolution. The first was linked to the wave of devolution (called décentralisation in French) which took place in 1983. Law No 83-8 of 7 January 1983 and Law No 83-663 of 22 July 1983 authorised the transfer of competences from the State to French departments (for trading and fishing ports) and to municipalities (for marinas) of more than 500 ports out of the total network. Though numerous, these ports only accounted for a limited share of France's port traffic, and less than $5 \%$ of tonnage. The transfer of competence from the State to the Local Government of Corsica of the ports of Ajaccio and Bastia was the second legislative procedure, via the Law of 22 January 2002. The convention implementing the transfer of responsibilities to local authorities for the concessions of these two ports was signed on 13 February 2004. It foreshadowed the terms of port devolution which was generalised by the Law of 13 August 2004, and which concern local freedoms and responsibilities.

The devolution of 2004 allowed ports of national interest to be transferred to regional local authorities in 2007 (Lorient, Brest and Saint Malo were transfered to the Brittany Region; Boulogne and Calais to the Nord pas de Calais Region; Bayonne to the Aquitaine Region; and Sète and Port-la Nouvelle to the Languedoc-Roussillon Region), to departmental local authorities (Toulon to the Département du Var; Nice to the Département des Alpes Maritimes), and to joint associations bringing together different local authorities (Cherbourg and Caen in Basse-Normandie in an association of the Region and its two departments; Dieppe in Haute-Normandie in an association including the Region, the Département SeineMaritime, as well as the Agglomeration Community and the City). This devolution drives the transition from a dual port model to a three-dimensional model. The former was characterised by dialogue between the State (the body ceding sovereign authority) and the Chambers of Commerce and Industry (responsible for the port concessions in the former ports of national interest). The three-dimensional port model includes the new concession authorities (the local governments), the concession-holders (mainly still Chambers of Commerce, even though it became possible to open up concessions to competition), and the State, which retains sovereign authority through the port policing. This system illustrates the singularity of French devolution which does not transfer sovereign nor legislative functions.

The waves of port devolution have not been subject to a sectoral policy that can be studied and understood as such. On the one hand, they are included in comprehensive reforms on the distribution of powers between the State and local authorities (Regions, Counties and cities). These reforms include multiple components: education, health, welfare, housing, 
transportation, etc. A new reform does not reflect a failure of the previous one. Instead, it means there is a gradual deepening of the process. Some sovereign functions, such as policing, remain the responsibility of the State, regardless of the port installation observed. ${ }^{4}$ However, the State cannot be seen as judge and jury: the ownership, investment, strategy, management, etc. are under the control of local authorities. Finally, local elected officials tend to favor the transfer of ports, while officials have called for a continuation of the process reports [Sénat, 2008]. However, this process is taking shape within in the political balance of power between the State and France's devolved Regions.

The reform of autonomous ports (2008): the new organisation of the Large Maritime Ports (Grands Ports Maritimes)

The status and organisation of France's main ports, with their autonomous status, was also reformed in 2008. Law No 2008-660 of 4 July 2008 transformed these autonomous ports (Le Havre, Marseille, Dunkirk, Nantes-Saint Nazaire, Rouen, La Rochelle, Bordeaux) into Large Maritime Ports (Grands Ports Maritimes). This law completed the long period of reform of France's main ports, which successively: i) altered the status of dockers (who became salaried employees in $1992^{5}$ ); ii) led to operation of these ports by private enterprise (the convention on operating terminals in 1999); iii) devolved ports (transferring the supervision of former ports of national interest to local authorities) in 2004; and iv) modified the status and operating conditions of autonomous ports in 2008. The reform of autonomous ports affected three main areas. The sale of equipment needed in operating terminals to private operators was a first point. It generalised the port concession system and the withdrawal of port authorities from operating activities. It implies the sale of public assets to private operators (cargo handling equipment) which are evaluated in the strategic projects of each port and subsequently controlled by a national evaluation commission of port equipment. These sales were accompanied by the transfer of port employees (crane operators) to private cargo handling companies. They involve a shift from the use of public law to private law, which aimed at ending the difference in status between vertical cargo handling (crane operators who were previously employees of the autonomous port) and horizontal cargo handling (dockers who were mainly employees of cargo handling companies). The third change involved the modification of governance which suppressed the classical French system of port presidency drawing on a board of directors, in favour of a tandem deemed to be more reactive and bringing together a directorate (3-4 members) and an supervisory board (17 members outside the port profession), supported by a development board (20-40 members from the port profession).

4 For ports alone, it also covers the maritime affairs administration, veterinary services/inspections, etc.

5 Prior to the reform, dockers were managed in each port, by a joint-management body comprising unions, the port authority and the private port handling companies. The dockers were recruited on a daily basis depending on the workload. This system relied upon a large supply of workers available to meet heavy load periods; and on financial compensation of their unemployment in periods of reduced port activity. 
This reform was set out in a national law and was completely transposed into local framework agreements by 2011. It corresponds to the changes in the ways of organising ports found throughout the world: i.e., a re-focussing of the functions of the port authority on development planning and regulation, and on the development of the private operation of ports. From a national point of view, this reform did not change the characteristic of a centralised State and hence its continued importance in governance (the right of veto in supervisory boards, the national evaluation commission which validates strategic projects). From a local point of view, though the reform was national, it was transposed in a variety of ways according to the specificities of each port. The specialised terminals, notably for container traffic of France's three large ports (Le Havre, Marseille and Dunkirk), were already operating along the lines proposed by the national law. These terminals therefore completed this transition. For multipurpose terminals with intermittent use in other ports, various types of derogations were put forward (port subsidiaries, semi-public companies). These allowed the port authorities to continue operating less profitable terminals which private actors were less inclined to take over. Overall, the reform of autonomous ports consolidated a port model that is similar to France's main European competitors (port terminals are operated within the framework of concessions, and public action is more focussed). But it retains specificities linked to the French context (the role of the State in public policy on ports) and the varied transposition at the local level, subject to local economic conditions.

\section{An Analysis of the Reform Process}

The decentralisation of ports: a process for modifying public organisation

The Law of 13 August 2004 transferred so-called ports of "national interest" to "full ownership" by local authorities and their groupings, free of charge, on 1 January 2007. It must be noted here that the notion of "full ownership" defines a historical choice by France, heralding the divestiture of the public port estate, a divestiture which had not taken place in the preceding phases of decentralisation. According to the terms of the law, "all local authorities or groupings of local authorities" had until 1 January 2006 to request the right to exercise the competences set out for each port, before possible arbitration by the State in case of multiple applications. The various stages of the process were planned in a short time: between 1 January 2006 (the deadline for applications for taking over one or several ports of "national interest") and 1 January 2007 (the transfer deadline). Where there was only one application, the transfer went ahead, subject to agreement by the State. In the case of multiple applications, a representative of the State (the Prefect) was charged with organising negotiations between the various interested local authorities. Prefects also made the final allocation choices where no agreements were reached or when there were no applicants. To organise these negotiations, the State sent audits of the ports of national interest to the various takeover candidates. These documents were very technical, identifying existing infrastructure within the perimeter of the port and presenting assessments of investments undertaken. The audits, however, did not provide data about the commercial aspects of ports' activities, or about their markets and the state of competition. Nor did they include any dynamic, forecasting analysis of the ports. As a result, local authorities often then found themselves 
commissioning further studies from consulting and market research firms, in order to draw up plans for the ports and the takeover projects. In fact, the evaluation of transferred ports was an important sticking point in negotiations between the State and local authorities. Three configurations of port authority finally emerged to take over from the State, once transfers were completed by 1 January 2007. They followed negotiations that were often difficult, and include: regional authorities, departmental authorities and forms of joint association linking the regional, departmental and local levels of administration.

These local authorities thus became the new port authorities (the licensing authority). Apart from having ownership of the ports, they are also responsible for defining ports' development strategy, for managing the ports' estates, managing developed projects and determining the regimes for port operations, and hence the choice of operators. These operators are in fact mainly Chambers of Commerce and Industry. The latter are the licensees responsible for the operating licences of public equipment and facilities, for variable lengths of time. The concessions in operation at the time of port transfer remained valid to their end date. The issue of creating competition between concessions, and hence the introduction of private capital, remains open for the time being. It must be noted that only Cherbourg has been opened up to a private operator - nine years after the transfer of authority. The public operation of devolved ports thus remains largely intact. Within this distribution of responsibilities, the State is still in charge of policing the environment, maintaining public order, of lighting, and of policing waters and dangerous materials. The local authorities are therefore responsible for development planning, maintaining and managing ports, while the State retains functions related to public order, and other sovereign functions.

The devolution process therefore led to port governance with a new distribution of responsibilities among public actors. Following the transfer, this governance has been based on a structure with three levels: i) the concessioning authority or licensor which is the new port authority and new "owner" of the port area and which ensures the management and development planning of the port(s) (i.e., the local authorities); ii) the concessionnaire which is responsible for operations and which holds the concession or licence to operate public equipment and facilities, under the supervision of the concessioning authority (the Chambers of Commerce and Industry), and iii) the State which continues to be responsible for sovereign functions and also the ultimate supervisory authority of the Chambers of Commerce and Industry. However, in practice, the State remains neutral regarding the strategy and management of the Chambers of Commerce. The link is based on the State's financial control of the accounts of Chambers of Commerce, but the relationships express more a formal link than an operational one.

The reform of Large Maritime Ports: regulatory processes for the rapid implementation of landlord port principles

New governance structures were set up quickly following the passing of the Law of July 2008, and its decrees of application in October and November which established the Large 
Maritime Ports (LMPs). ${ }^{6}$ The overhaul of the governance of LMPs ended the situation in which ports' boards were both "judge and jury", deciding on strategy, managing its implementation and controlling its proper implementation. The General Directorates merely had the mission of applying decisions by port boards. There is a clear separation of powers in the new organisation, based on a Supervisory Board which validates and controls the strategy put forward and implemented by the Directorate. Consultative development boards bring together stakeholders in ports' development, including: local authorities, port enterprises, port users and experts, etc.

This governance translates new equilibria: the State has reinforced its control over the supervisory boards, holding $29.4 \%$ of the seats, compared to $11.5 \%$ previously. Local authorities, which have had authority over decentralised ports since 2004, have lost seats in these decision-making bodies. Similarly, cargo handling companies, while acquiring sole command over terminals, have lost all representation in the decision-making bodies. Companies and local authorities criticise this distribution however, even though they participate more and more in the financing and success of strategic projects.

A strategic plan for five years is formulated by the Directorate of each LMP, in consultation with the development board, and is then submitted for approval by the supervisory board, prior to additional acceptance by the Ministry of Transport. These strategic plans are the basis of multi-year contracts between the LMPs, the State and the relevant local authorities. The contracts set out the implication of the stakeholders in the implementation of projects as well as the State's dividend policy. The first strategic projects were drafted very quickly (within a few months), at a time of considerable uncertainty due to the crisis in 2008, when the immediate issue at stake revolved around the transfer of equipment and personnel to private cargo handling companies. Thus, the strategic projects for the years 2009-2014 manifest ambitious plans defined before the crisis, concerning the containerisation and logistics sectors in particular. But the subsequent reality has largely undermined initial objectives. Above all, these strategic projects detailed the means for managing each terminal: the operator, the equipment and personnel to be transferred, the role of the port authority (subsidiary, shareholdings) etc.

Generally speaking, equipment has been sold at prices below its real value. Sale prices in fact corresponded more to the overall conditions under which the private operators took over terminals, rather than value of equipment itself. Overcapacity of equipment and personnel, low productivity, and mediocre economic prospects all impacted on the amortisation of equipment and were factors taken into account during takeover negotiations. Port authorities on the whole favoured takeover solutions that reduced the number of derogations in the new governance structure, even when such solutions were disadvantageous. Indeed, the law states that port authorities may continue to carry out cargo handling for five years at most, should tenders for terminal concessions fail. After five years, a new call for tender has to be made. This was especially the case for several terminals at Nantes Saint-Nazaire. Furthermore, port

6 Decrees 2008-1033 to 2008-1038 relate to the creation of large maritime ports in Nantes SaintNazaire, Bordeaux, Marseille, Dunkirk, Le Havre and La Rochelle; Decree 2008-1146 relates to the creation of the large maritime port at Rouen. 
authorities have sometimes set up joint-ventures with private companies to manage terminals such as in Bordeaux.

The personnel driving and maintaining equipment were seconded to cargo handling companies, according to agreements between the port authorities, the handling companies and the employees concerned, guaranteeing the rights of the latter (in terms of seniority, pay, etc.). In addition, the national framework agreement of 30 October 2008 gave each employee the possibility to return to the port authority payroll, within a period of three years following secondment. Lastly, employees have been guaranteed the possibility of going back to work for the port authority in case of redundancy. This protection covers the first seven years of secondment, and was negotiated port-by-port, and in some cases runs to 25 years (Marseille, Le Havre, Dunkirk). These personnel transfers took place between 2010 and 2011, with the aim of minimising deadlocks as much as possible, as borne out by the guarantees given to employees.

\section{The results: the outcomes of changing port governance vs. industrial port policies}

The transfers of ports of national interest: reviewing the question of ports in a time of crisis

The consequences of the devolution of ports of national interest are hard to measure. These reforms have been recent, as ports were transferred on 1 January 2007. At the same time, the takeover of ports by local authorities occurred in a period of economic crisis and aggravated deindustrialisation. Traffic through ports between 2007 and 2015 was first characterised by falls, followed by a limited pick up, so that traffic returned to levels similar to 2007. In terms or port throughput, the reforms have not led to a rise in activity. Nevertheless, a detailed analysis of some ports (Lorient, Saint Malo, Brest, Nice and Dieppe) does show up four significant changes brought about by reform. First of all, these devolved ports have seen new policies and new strategies emerge. The new port authorities (local authorities) have indeed provided new funding to maintain existing activities (concerning passenger traffic, boating and ship repair, various bulk activities, food shipment, and fishing, etc.). New activities have also been developed, especially concerning renewable energies (wind power). Many projects have also been financed within the context of strategic regional and departmental plans, drawing on the search for synergies between devolved ports. Funding is being provided on the one hand by local authorities themselves, and on the other hand as part of project contracts bringing together the State and local authorities. Second, control over port concessions has been strengthened. To be sure, the monopoly of Chambers of Commerce and Industry has not been challenged, and the renewal of concessions has allowed these monopolies to be maintained. But the negotiations over port concessions have also permitted local authorities to set important commercial and industrial objectives, while rebalancing the respective powers of the port authorities and port operators. The third factor concerns the changes linked to the reassessments of town-port relations. To be sure, urban local authorities (municipalities) have played a secondary role in the devolution process. But the change in port authorities has allowed negotiations between towns and ports to be restarted, especially within the framework created by the strategic boards in the wake of reforms. Analysis of urban planning documents for port towns (the Schéma de Cohérence Territorial, Plan de Déplacement Urbain, and 
Agenda 21) highlights the rising interest in ports in relationship to urban planning, from the point of view of interfaces between towns and ports (improved access, reduced urban pollution, landscaping charters, etc.), but also from the point of view of economic development projects (new logistics zones). Lastly, change has also led to heightened consideration of environmental issues in port management. Local authorities have included port matters in their sustainable development objectives, creating new standards (ISO and AFNOR) for environmental management (dredging, water quality and noise pollution). New charters have also been established with industrialists, to limit visual and noise pollution by industrial activities (management of operating hours, development of new infrastructure).

Large Maritime Ports: compromise-based reform and a national port strategy whose tools need to be improved

Less than ten years after coming into force, the reform has been broadly welcomed by the parties involved, though they have stated some criticisms. One major critique concerns the maintenance, if not strengthening, of State supervision over Large Maritime Ports, even though the State's financial participation has tended to decline. The rise in funding provided by the State in the wake of reform was only temporary. Local authorities and companies believe their place in governance to be too weak relative to the roles they play. A report by France's Senate in 2011 stressed in particular the lack of local attachment of the LMPs, compared to the involvement of local authorities in port management in Spain, Germany and the Benelux countries. France's parliament has recently taken these criticisms into account partially, though taking care not to change the balance of power in LMP governance. Thus, Article 3 of the Law on the Blue Economy (loi sur l'économie bleue, 2016) sets up investment commissions within each development board, in order to position ports better with respect to public investment.

Table 2: Trends in Operating and Investment Funding Attributed to Large Maritime Ports, since 2007

Graph 1: Trends in Funding Dedicated to Transport and Ports by the State and Local Authorities, during the State-Region Contracts for 2007-2013 and 2015-2020

The State is also criticised for lacking a national port strategy, given its powers of control over LPMs. This strategy is currently based on the whole set of strategic projects by the LMPs, which have to be consistent with the positions of the boards of inter-port coordination, to which ports are linked administratively. There are two such boards, one for the LMPs on the Atlantic (Nantes Saint-Nazaire, La Rochelle and Bordeaux), and another for the LMPs on the

\footnotetext{
$7 \quad$ CPER: contract between the State and the Regions for a period of seven years of programming and multi-year funding of major projects (such as the creation of infrastructure and support for economic clusters). The three regions mentioned in the graph (Haute Normandie, Nord Pas de Calais, PACA) grouping for of the seven Large Maritime Ports.
} 
Seine (including the port of Paris). The boards are meant to limit competition between LMPs. ${ }^{8}$ It is still too early to assess the effects of these coordination boards, but their opinions are formulated on the basis of consensus and are little-constraining for LMPs. Consultation and development bodies have been created by the LMPs, such as the Haropa on the Seine axis. The latter brings together port authorities from Le Havre, Rouen and Paris, with results that are more in line with the spirit of the law, as borne out by the strategic projects of these three ports for 2014-2019. Lastly, while the LMPs may enter into cooperative agreements with devolved ports, in practice this legal possibility has not been much used since the Law of 2008. In fact, competition and mistrust seem to prevail between ports of very different sizes and structures.

In 2013, within the framework of the preparation of the second wave of strategic projects (2014-2019), the State set out the objectives of the LMPs in a National Plan for Port Recovery (Plan national de relance portuaire). This framework document indicates priority aims and actions that ports must implement in the coming years, in three major areas, namely logistics, the environment and industry. The strategic projects for 2014-2019 strive to meet these objectives, and detail how priority actions are to be implemented. Actions favouring industry are now to be a key component of LPM strategies, as the sector was ignored for a long time in favour of logistics.

The outcomes of the transfer of activities to private cargo handling companies can only be understood with respect to the goals and principles followed by France's parliament. The aim here has been to generalise the emergence of a single command structure for terminals, even if this means creating joint-ventures associating private companies and port authorities. This has indeed occurred in a limited number of cases. Provisions have also been made for derogations, restricted in time in order to reduce risks that terminals will not have operators: port authorities may therefore retain their cargo handling functions for five years ${ }^{9}$. Moreover, France's parliament has favoured direct agreement procedures with existing companies. This has facilitated transfers (due to knowledge of tools, equipment and practices) and has limited risks of destabilising ports' positioning during this delicate period. Calls for tender are only launched when these procedures fail. This policy has potentially blocked the entry of new actors. Thus, while a majority of terminals are henceforth exploited by private companies with a single command structure, specific cases remain. Experts at the Court of Accounts also consider that port equipment was sold off at less than its value.

\footnotetext{
8 The inter-port boards were created by the reform Law of 2008, bringing together the local authorities concerned, the State, the presidents of the directorates of the ports concerned, as well as the managers of river and rail transport infrastructures. The aim of these boards is to avoid duplications in investments, and to promote complementary projects, etc.

9 Port terminals with a low critical mass experienced financial difficulties, regardless of the selected management method (public or private operator). This has been true in the LMPs (e.g., the container terminal Bordeaux Le Verdon) and in decentralised ports (e.g., the fruit terminal of Sète). The law allows for the maintenance of a public operation through a public subsidiary or through a delegation to a private company (Régie). These interim solutions clearly raise the question of the future of these terminals in a difficult competitive and legal environment. The reforms only partially answer this question.
} 
Taking into account the social issues was also a prerequisite in starting the 2008 reform: legislators wished to avoid blockages in the LMPs and to limit competition distortion with decentralised ports. Thus, on the one hand, there have been many possible adjustments to personnel transfers (employees) to the private sector, as shown in Section 3. On the other hand, "the negotiation of a common national collective agreement for port handling and port management institutions [was] the means to provide social guarantees to all personnel providing services to the ports, including the administration, operation, handling and maintenance of quay tools, and to harmonise their employment and remuneration conditions" [Convention collective nationale unifiée ports et manutention, 2011].

These results are inherent in the method used: the 2008 reform is based on the principle of "port-by-port" change, initiated by Ambroise Guellec, Deputy-minister for the Sea, in 1986: once the broad outlines of a reform policy have been set, their detailed implementation should be organised locally, port-by-port. The stakeholders within each port area must negotiate within the boundaries set out by the reform. Choices are made as a function of the needs, opportunities and constraints of each port. The advantage of this principle lies in the flexibility of applying reforms and in their adaptation to local constraints and issues. The large maritime ports have very diverse traffic, they face different competitive situations, and their port situations are more or less dynamic or conservative. Ports therefore react differently to regulatory changes imposed on them (by reforms) or proposed (through experimentation). ${ }^{10}$ Thus, since the 1980s, parliament has sought to take into account such differences by associating general guidelines with local variations, according to pre-determined choices that stakeholders can negotiate on, at port level. The major drawbacks lie in the persistence of previous practices in disguise, in the implementation of legal solutions that contravene the spirit of the law and which potentially slow down the intensity of reform as well as its capacity to meet initial objectives fully. The most dynamic port sites may fully use the new possibilities provided by the reform, whereas more conservative ports can benefit from options that challenge existing organisational practices less. The competitive spread between ports may rise with each new reform, deepening path dependency which weighs on future reforms.

\section{A summary assessment of reforms}

In the final analysis, the evaluation (objectives/results) of these recent reforms is difficult. Such evaluation involves distinguishing three elements: port traffic, reform of the organisational model of ports, and the revival of a strategy. To begin with, the reforms studied were aimed at restoring traffic and increasing the shares of France's main ports in the European market. However, save in special cases, the traffic of ports affected by these reforms has not increased significantly in recent years. It has even declined in some cases, as

$10 \quad$ Experiments are following the same logic: The parliament creates a new possibility, which is a derogation to the classical legal framework (a contract model, a type of legal status for companies, a tax concession, the authorisation to create new partnerships, etc.). Each port can then decide whether to use this opportunity. The standard conventions covering the operation of terminals (created in 1999) are like this. 
in Le Havre in the container shipping segment (2007-2011). But, these observations alone cannot lead to the conclusion that the reforms have failed, as they occurred during a global economic crisis which has greatly weakened the port sector at the European level. Not enough time has passed since the reforms to assess their impact on the dynamism of the French port sector. Secondly, the reforms have aimed at improving the functioning of the port authorities from a New Public Management perspective. For ports of national interest, decentralisation ensures a greater proximity between managers and political supervisors, in accordance with the principle of subsidiarity. In the case of the major seaports, this improvement was to have occurred firstly via the transfer of capital equipment to the private sector. This objective has generally been achieved, but there have also been difficulties for port terminals that are little attractive. The intervention of port authorities via subsidiaries thus remains necessary, as is the case in Bordeaux. Handling staff should also have to be transferred in order to lower the payroll of the port establishments. Many transfers have taken place, but recent reports by the Court of Accounts [2014, 2015a and b] consider that the reduction in payrolls is still insufficient, in particular because some of the staff concerned have been reclassified within maintenance subsidiaries of the port authorities. Finally, the 2008 reform aimed at reorganising the financial management of the port authorities, by setting up audit committees within the governance bodies. The results from this point of view have been mixed. Some ports, such as Rouen, have seen their situation improve [Court of Accounts, 2014]. But the reforms have not provided any solutions to debt problems (Nantes-Saint-Nazaire), and to operating deficits experienced by other ports (Bordeaux). Thirdly, the reforms nevertheless constitute a significant turning point in France's port policy, over the long term. After three decades of political marginalisation, ports are again receiving renewed attention from policymakers. Following the decentralisation in 2004, local and regional authorities have developed ambitious port policies. As for the State/central government, it has an explicit port strategy, which it is implementing via its supervision of France's major seaports. The main limits highlighted by recent expert reports concern the weaknesses of inter-port coordination, whether at the level of the inland river corridors (the Seine and Rhône) or on the Atlantic façade. Existing inter-port authorities have been encouraged to broaden their scope of action, in order to integrate strategic issues such as investment coordination, while expanding the perimeter of their activities [Fourneyron and Revet, 2016; Lambert and Lamure, 2016; Vaugrenard, 2016]. A secondary objective here is to strengthen the implementation of the national port strategy by avoiding the dispersion of credits.

\section{Conclusion. A French Form of Port Devolution}

The French case provides an interesting example of the evolution of port governance. In terms of managerial implications, the two reforms analysed here bear witness to the redefinition of the public sphere, to the greater contribution of private operators, to the importance accorded to negotiation during the implementation phases, to the transposition of the general model of reform according to the specificities of every port. If the reforms are translated by a general reorganisation of the relations between stakeholders (public-private), they are nevertheless transformed by local contexts. Based on devolution (regional ports) and the generalisation of 
the landlord model (the Large Maritime Ports), the French port model appears on the whole to follow port changes throughout the world. The French port system is also characterised by a recent phase in devolution that has modified public and private responsibilities in port management and supervision. The role of the State (central government) continues to be important in the new port governance structures, both in terms of supervising devolved ports (sovereign functions, control over the accounts of Chambers of Commerce and Industry), as well as in the overall management and supervision of the Large Maritime Ports (veto rights, approval of strategic projects and the appointment of port directors). That said, these overall changes are transposed in a variety of ways, depending on the realities of each particular port site. France's main ports therefore function in a way quite similar to the landlord model. Smaller ports operate with a hybrid model, between the generalisation of port concessions and the maintenance of public operation. Regional and local ports are still based on the public model. The "size effect" is an important factor in explaining the organisation of ports. The French case also illustrates the complexity and heterogeneity which exists within the public model. In analytical approaches to governance, the public and private organisations are often held to be homogenous opposites. However, to understand the organisation of ports, it is important to take into account their spatial and legal complexity (Olivier \& Wang). This allows for the heterogeneity of public organisation and its impact on port governance to be understood (Debrie, 2010). In the management of French ports, the complex relationships between the State and local authorities are also identified in many official reports as a problem for port efficiency. Lastly, these question of the impact of these reforms on port efficiency remains hard to measure. Port reforms have occurred recently in France, and have unfolded in a context of marked economic crisis. The reforms have not been able to avoid falls in activity and in particular a worsening of deindustrialisation processes. We believe it is important to conclude with this observation. Port efficiency depends above all on an industrial strategy, and this goes beyond the issue of port governance.

\section{References}

Bird, J., 1963, The major seaports of the United Kingdom, London : Hutchinson.

Brooks M R, Pallis A A, 2010. Port governance. Maritime Economics Ed W T Talley (A Blackwell Companion, Blackwell Publishing Ltd.) Chapter 26.

Brooks M R, Pallis A A, 2008. Assessing port governance models: process and performance components. Maritime Policy \& Management 35(4) 411-432.

Brooks M. R., Cullinane K., 2006, "Port Governance”, in: Brooks M. R., Cullinane K (eds), Devolution, Port Governance and Port Performance, Oxford: Elsevier, p. 3-28.

Cariou, P, Fedi, L, Dagnet F, 2014. The new governance structure of french seaports : an initial post-evaluation. Maritime Policy Managment, vol 41, issue 5, 430-443.

Comtois C, Slack B, 2003. Innover l'autorité portuaire au $21^{\text {ème }}$ siècle: un nouvel agenda de gouvernance. Les Cahiers Scientifiques du Transport, 44, 11-24.

Cour des comptes, 1999, La politique portuaire française: rapport au Président de la République suivi des réponses des administrations et des entreprises intéressées, rapport public particulier, Paris : Documentation française. 
Cour des comptes, 2006, Les ports français face aux mutations du transport maritime: l'urgence de l'action, rapport public thématique, Paris : Documentation française.

Cullinane K P B, Song D W, 2002. Port Privatisation Policy and Practice. Transport Reviews $22,55-75$.

Damette F., Scheibling J., 1995, La France: permanences et mutations, Paris : Hachette.

Debrie J., Lavaud-Letilleul V., Parola F, 2013. Shaping port governance: the territorial trajectories of reform. Journal of transport Geography, vol 27, 2013, 56-65.

Debrie J., Lavaud-Letilleul V. (dir.), 2010, La décentralisation portuaire : réforme, acteurs, territoires, Paris : L'Harmattan.

De Langen P, Van der Lugt L, 2007. Governance structures of port authorities in the Netherlands. Devolution, Port Governance and Port Performance, Research in Transportation Economics Eds M R Brooks, K P B Cullinane (Elsevier, London, UK) 17(1) 109-137.

Fourastié, J., 1979, Les Trente Glorieuses: Ou la révolution invisible de 1946 à 1975, Paris : Fayard.

Frémont, A., 2005, Conteneurisation et mondialisation. Les logiques des armements de lignes régulières, Habilitation à diriger des recherches, Université Panthéon-Sorbonne - Paris I.

Hall P V, 2003. Regional Institutional Convergence? Reflections from the Baltimore Waterfront. Economic Geography, 79, 347-363.

Lacoste, R, Gallais-Bouchet, A, 2012. Analyse qualitative des outils de coordination et de cooperation dans le cadre de la politique portuaire française: le cas des Grands Ports Maritimes. L'espace politique, 16, http://espacepolitique.revues.org/2224 ; DOI : 10.4000/espacepolitique. 2224

Ministère de travail, de l'emploi et du dialogue social, 2011, Convention collective nationale unifiée ports et manutention, IDCC 3017, 15 avril.

Ng A K-Y, Pallis A A, 2010. Port governance reforms in diversified institutional frameworks: generic solutions, implementation asymmetries. Environment and Planning A 42(9) 21472167.

Sénat, 2008, Rapport $n^{\circ} 331$ fait au nom de la commission des Affaires économiques sur le projet de loi portant réforme portuaire (urgence déclarée), par M. Charles REVET, Sénateur.

Verhoeven P, 2010. A review of port authority functions: towards a renaissance? Maritime Policy \& Management 37(3) 247-270.

Vigarié, A., 1984, « Les ports de commerce français de 1965 à 1983 », Norois, 121(1), 15-29.

Wang J J, Ng A K-Y, Olivier D, 2004. Port governance in China: a review of policies in an era of internationalizing port management practices. Transport Policy, 11, 237-250.

\begin{abstract}
The French model of port governance has experienced change recently, characterised by two successive reforms that have modified the status of ports. The Law of 13 August 2004 relating to the responsibilities of local authorities (including the devolution of 17 ports of "national interest"), and the reform of seven autonomous ports (given the status of Large Maritime
\end{abstract}


Ports) in 2008 have restructured the evolution of the public organisation of French ports. They have also modified the relationship between port authorities and private operators. The aim of this chapter is to analyse these two reforms and their consequences for port governance. In terms of the devolution of regional ports and the generalisation of the landlord model for major ports, the French model appears to be quite similar to the general trend to devolution of ports throughout the world. Nevertheless, the place of the State (i.e. France's central government) remains important, in the supervision of devolved ports as well as of Large Maritime Ports. Yet, this overall change is transposed variously according to the local context of each port. The transposition of national reforms has led to specific arrangements, so that the port governance model is more complex.

\section{Key words :}

French ports, port policy, reform, local negociations 